\title{
Syntheses and In Vitro Biological Activity of Some Derivatives of C-9154 Antibiotic
}

\author{
Isaac Asusheyi Bello, ${ }^{1,2}$ George Iloegbulam Ndukwe, ${ }^{2}$ Joseph Olorunju Amupitan, ${ }^{2}$ \\ Rachael Gbekele Ayo, ${ }^{3}$ and Francis Oluwole Shode ${ }^{1,4}$ \\ ${ }^{1}$ School of Chemistry, University of Kwazulu-Natal, Durban-4000, South Africa \\ ${ }^{2}$ Department of Chemistry, Ahmadu Bello University, Zaria-810001, Nigeria \\ ${ }^{3}$ College of Agriculture, Division of Agricultural Colleges, Ahmadu Bello University, Zaria-810001, Nigeria \\ ${ }^{4}$ Department of Chemistry, Faculty of Science and Agriculture, University of Zululand, KwaDlangezwa-3886, South Africa
}

Correspondence should be addressed to Isaac Asusheyi Bello, lobell_ng@yahoo.com

Received 29 May 2012; Accepted 30 October 2012

Academic Editor: Armando Rossello

Copyright ( 2012 Isaac Asusheyi Bello et al. This is an open access article distributed under the Creative Commons Attribution License, which permits unrestricted use, distribution, and reproduction in any medium, provided the original work is properly cited.

\begin{abstract}
In our continued attempts at designing new antibiotics based on the structure of the C-9154 antibiotic, to simultaneously improve activity and lower toxicity, an analogue to the C-9154 antibiotic and six derivatives of this analogue were synthesized. The approach was to significantly reduce the polarity of the synthesized analogue in the derivatives to achieve increased permeability across cell membranes by conversion of the highly polar carboxylic group to an ester functional group. The compounds were synthesized using a two-step reaction which involved an additional reaction between benzyl amine and maleic anhydride and then conversion of the terminal carboxylic acid functional group to an ester functional group using a thionyl chloride mediated esterification reaction. The compounds were fully characterized using Infrared, GC-MS, and 1D and 2D NMR experiments. The in vitro biological activity of the compounds showed that the derivatives were more active than the analogues as was anticipated with minimum inhibitory concentration in the range $0.625-5 \mu \mathrm{g} / \mathrm{mL}$. The analogue had minimum inhibitory concentration in the range $2.5-10 \mu \mathrm{g} / \mathrm{mL}$. These values are significantly better than that obtained for the original C-9154 antibiotic which had activity in the range $10->100 \mu \mathrm{g} / \mathrm{mL}$.
\end{abstract}

\section{Introduction}

In 1889, Vuillemin, a French bacteriologist, suggested using the word "antiobiosis", meaning "against life," to describe the group of drugs that had action against microorganisms [1]. Selman Waksman, an American microbiologist and the discoverer of streptomycin, later changed this term to antibiotic in 1942 [2]. The term "antibiotic" as coined by Selman Waksman is used to describe any substance produced by a microorganism that is antagonistic to the growth of other microorganisms in high dilution (low concentration). This definition excluded substances that kill bacteria but are not produced by microorganisms such as gastric juices and hydrogen peroxide [3].
Antibiotics today, with advances in medicinal chemistry, are semisynthetic modifications of various natural compounds [4]. These include, for example, the Beta-lactam antibiotics, which include the penicillins, the cephalosporins, and the carbapenems. Some antibiotic compounds are still isolated from living organisms like the aminoglycosides, whereas other antibiotics like the sulfonamides, the quinolones, and the oxazolidinones are produced solely by chemical synthesis [4]. This implies that synthesis of antibiotic compounds plays an important and vital role in the fight against disease-causing organisms.

In light of emerging resistance to antibiotic drugs, it has become imperative to synthesize new drugs with improved activity to combat various illnesses that have developed 
resistance to existing treatments. The problem of resistance to antibiotics on the part of the microorganism, the adverse side effects associated with antibiotics in current use and the difficulty in obtaining these antibiotics in large (commercial) quantities from their natural sources implies that newer antibiotics have to be constantly sought for, to address these problems to give man the needed advantage in the ongoing battle between microbes and men. Synthesis of previously characterized antibiotics with structural modifications to imbue desirable qualities or remove undesirable ones provides a way to assist man in this great battle.

During studies on screening for antibiotics that showed activity against bacteria resistant to various known antibiotics, a new antibiotic with a broad antibacterial spectrum was isolated from the whole agar culture of Streptomyces strain NR-7GGI. This Streptomyces species was called Streptomyces kurssanovii and the isolated antibiotic referred to as fumaramidmycin [5].

Another researcher working independently and slightly earlier than the previous researcher also found that a new species of Streptomyces, Streptomyces ishigakiensis produced a novel antibiotic which was named C-9154 [6].

The two new antibiotics were found from structural studies to be the same compound $[6,7]$. This new antibiotic was found to inhibit the growths of various microorganisms at concentrations between $10->100 \mu \mathrm{g} / \mathrm{mL}$ [6]. It was also shown to be active against certain strains that were resistant to ampicillin, cephalosporin, chloramphenicol, gentamicin, kanamycin, macrolides, neomycin, sulfonamides, streptomycin, and tetracyclines at concentrations between 3.12$>200 \mu \mathrm{g} / \mathrm{mL}$ [5]. Its intraperitoneal $\mathrm{LD}_{50}$ value in mice was found to be between $75-100 \mathrm{mg} / \mathrm{kg}$ while its oral $\mathrm{LD}_{50}$ was found to be $1.25-2.5 \mathrm{~g} / \mathrm{kg}$ [5].

The structure of C-9154 (Figure 1) was determined using elemental analysis procedures, IR and UV measurements, and NMR and GC-MS experiments [6, 7].

Analysis of the structure of C-9154 antibiotic showed that it was made up of two fragments, namely, phenylacetic acid and fumaramide $[6,7]$.

Analogues of the C-9154 antibiotic have been previously synthesized [7-10]. These analogues were shown to have antibacterial activity against Staphylococcus aureus and Escherichia coli ranging from $15 \mu \mathrm{g} / \mathrm{mL}$ [10] to $4000 \mu \mathrm{g} / \mathrm{mL}$ [9].

\section{Materials and Method}

Infrared spectra were determined using a PerkinElmer Spectrum 100 series Universal ATR. 1D and 2D NMR experiments were carried out using a Bruker av $400 \mathrm{MHz}$ NMR. The gc-ms spectra were taken using an Agilent Technologies 6890 series GC coupled with an Agilent 5973 Mass Selective detector. All chemicals and reagents unless otherwise stated were obtained from Merck Chemicals, Germany.

2.1. Synthesis of C-9154 Analogue. The analogue was synthesized using the following procedure. N-benzyl fumaramic acid was prepared according to reaction scheme 1 (Figure 2).

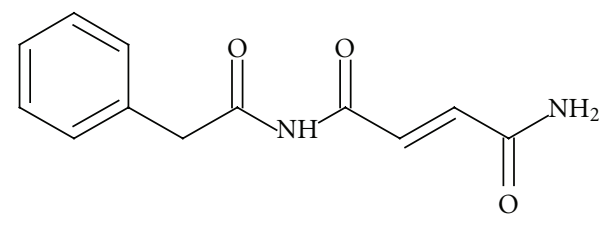

FIGURE 1: C-9154 antibiotic.

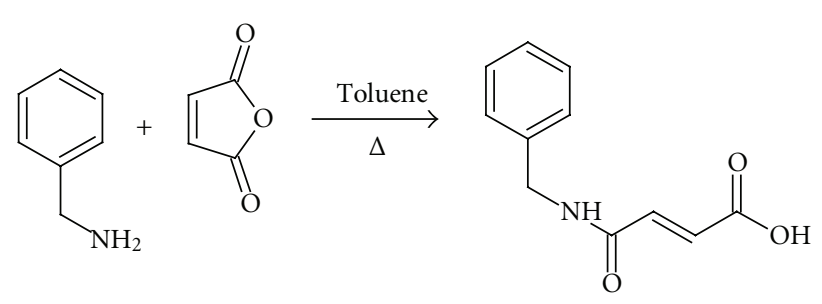

Figure 2: Reaction scheme 1.

Benzylamine $(1.0 \mathrm{~g}, 9.3 \mathrm{mmol})$ in toluene $(5 \mathrm{~mL})$ was transferred to a round bottom flask containing maleic anhydride $(1.1 \mathrm{~g}, 11.2 \mathrm{mmol})$ in toluene $(5 \mathrm{~mL})$. The mixture was refluxed with stirring for $3 \mathrm{hrs}$. The reaction was allowed to cool to room temperature and filtered using a Buchner funnel. The residue was washed using ethyl acetate and dried to afford a shiny white solid labeled IA/12/1 (1.76 g, 91.7\%). TLC was used to determine that the reaction had gone to completion. IR, 1D and 2D NMR, and GC-MS were used to identify the compound as the desired N-benzyl fumaramic acid. Its melting point was determined to be $125-127^{\circ} \mathrm{C}$.

2.2. Synthesis of Derivatives of C-9154 Analogue. This analogue was then converted to its ester derivatives using methanol, ethanol, n-propanol, isopropanol, n-butanol, and 2-butanol, respectively, using a thionyl chloride $\left(\mathrm{SOCl}_{2}\right)$ mediated esterification process, according to reaction scheme 2 (Figure 3).

Six portions of IA/12/1 $(0.5 \mathrm{~g}, 2.4 \mathrm{mmol})$ were individually transferred to six round-bottomed flasks in ice baths. Thionyl chloride $(2 \mathrm{~mL})$ was added in drops with constant stirring. The excess thionyl chloride was removed using a rotary evaporator. Methanol $(10 \mathrm{~mL})$, ethanol $(10 \mathrm{~mL}), \mathrm{n}$ propanol $(10 \mathrm{~mL})$, isopropanol $(10 \mathrm{~mL})$, n-butanol $(10 \mathrm{~mL})$, or 2-butanol $(10 \mathrm{~mL})$ were added to each flask and the mixtures refluxed. At the end of the reactions as determined by TLC, saturated sodium carbonate $\left(\mathrm{Na}_{2} \mathrm{CO}_{3}\right)$ solution was added to each flask until the solutions just turned alkaline as indicated by litmus paper. Water $(20 \mathrm{~mL})$ was added to each flask and the mixtures were individually transferred to different separatory funnels. The mixtures in the different separatory funnels were extracted using dichloromethane $(2 \times 25 \mathrm{~mL})$. The combined dichloromethane fractions were then individually dried using anhydrous sodium sulphate $\left(\mathrm{Na}_{2} \mathrm{SO}_{4}\right)$ and concentrated to give clear oils. These were chromatographed on silica gel columns and eluted using ethyl acetate: hexane $(3: 7)$, to give the desired esters which crystallized on standing. All the esters were obtained as crystalline solids (Table 1) except the methyl and butyl esters 


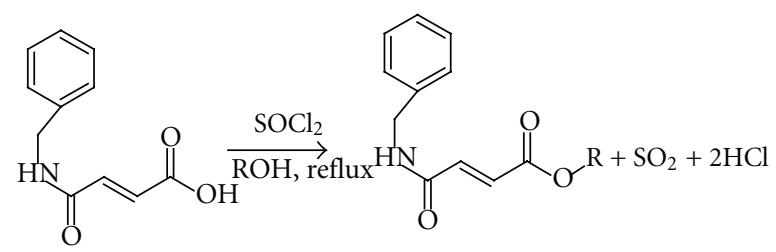

Where $\mathrm{R}=\mathrm{CH}_{3}$

$$
\begin{aligned}
& \mathrm{CH}_{3} \mathrm{CH}_{2} \\
& \mathrm{CH}_{3} \mathrm{CH}_{2} \mathrm{CH}_{2} \\
& \left(\mathrm{CH}_{3}\right)_{2} \mathrm{CH} \\
& \mathrm{CH}_{3} \mathrm{CH}_{2} \mathrm{CH}_{2} \mathrm{CH}_{2} \\
& \left(\mathrm{CH}_{3} \mathrm{CH}_{2}\right)\left(\mathrm{CH}_{3}\right) \mathrm{CH}
\end{aligned}
$$

Figure 3: Reaction scheme 2.

which were obtained as colourless oils. IR, 1D and 2D NMR, and GC-MS were used to identify the compounds as the desired esters.

2.3. Biological Screening. The analogue and its derivatives were successfully synthesized and characterized. These compounds were then subjected to biological screening in vitro to ascertain their activity and the concentration at which this activity was exhibited.

This was carried out using Zones of inhibition measurements, Minimum Inhibitory Concentration measurements, and Minimum Bactericidal/Fungicidal Concentration measurements. Fourteen (14) microorganisms were selected for the screening to include both gram-positive and gram-negative bacteria and some fungi. These microorganisms are Methicillin-Resistant Staphylococcus aureus, Staphylococcus aureus, Streptococcus pyogenes, Bacillus subtilis, and Corynebacterium ulcerans for gram-positive bacteria, Escherichia coli, Proteus mirabilis, Pseudomonas aeruginosa, Salmonella typhii, Shigella dysenteriae, and Klebsiella pneumonia for gram-negative, and Candida albicans, Aspergillus nigre, and Trichophyton rubrum for fungi.

2.4. Zones of Inhibition. The antimicrobial activity (Table 2) of the synthesized analogues and derivatives was determined using some pathogenic microorganisms obtained from the Department of Medical Microbiology, Ahmadu Bello University Teaching Hospital, Zaria, Nigeria. All isolates were checked for purity and maintained in slants of blood agar.

The analogue $(0.1 \mathrm{mg})$ and the derivatives $(0.05 \mathrm{mg})$ were each weighed and dissolved in DMSO $(10 \mathrm{~mL})$ to obtain concentrations of $10 \mu \mathrm{g} / \mathrm{mL}$ and $5 \mu \mathrm{g} / \mathrm{mL}$, respectively. This was the initial concentration used to check the antimicrobial activities of the compounds. Mueller Hinton, (Oxoid, England) and Sabouraud agar, (Oxoid, England) were the growth media used for the bacteria and fungi, respectively. The media were prepared according to the manufacturer's instructions, sterilized at $121^{\circ} \mathrm{C}$ for 15 minutes and were poured into sterile Petri dishes. The plates were allowed to cool and solidify.
Diffusion method was used for screening the compounds. The sterilized media were seeded with a standard inoculum $(0.1 \mathrm{~mL})$ of the test microorganisms. This was spread evenly over the surface of the plate by using a sterile swab. The plates were dried at $37^{\circ} \mathrm{C}$ for 30 minutes. Using a standard cork-borer of $6 \mathrm{~mm}$ in diameter, a well was cut at the centre of each seeded plate. $0.1 \mathrm{~mL}$ of the compounds was then introduced into the well. The plates were then incubated at $37^{\circ} \mathrm{C}$ for $24 \mathrm{hrs}$ for the bacteria and $30^{\circ} \mathrm{C}$ for $48 \mathrm{hrs}$ for the fungi, after which the plates were observed for zones of inhibition of growth. The zones were measured using a pair of dividers and a ruler and the result recorded in millimeters.

The activity of the compounds was compared against two standard drugs; Sparfloxacin (antibacterial) and Fluconazole (antifungal).

2.5. Minimum Inhibitory Concentration. The minimum inhibitory concentrations (Table 3 ) of the compounds were carried out using broth dilution method. Mueller Hinton, (Oxoid, England) and Sabouraud dextrose broth, (Oxoid, England) were prepared and $10 \mathrm{~mL}$ was dispensed into test tubes and the broths were sterilized at $121^{\circ} \mathrm{C}$ for 15 minutes, the broths were allowed to cool.

McFarland's turbidity scale number 0.5 was prepared to give a turbid solution. Normal saline was prepared and the test microorganisms were inoculated and incubated at $37^{\circ} \mathrm{C}$ for 6 hrs. Dilution of the test microorganisms was done continuously in the normal saline until the turbidity matched that of the McFarland's scale by visual comparison. At that point the test microbe was at a concentration of about $1.5 \times 10^{8} \mathrm{CFU} / \mathrm{mL}$. Twofold serial dilutions of the compounds in the broth were made to obtain the different concentrations of the compounds in the broth. Having obtained the different concentrations, $0.1 \mathrm{~mL}$ of the standard inoculum of the test microorganisms in the normal saline was then inoculated into the different concentrations, and then incubated at $37^{\circ} \mathrm{C}$ for $24 \mathrm{hrs}$ for the bacteria and $30^{\circ} \mathrm{C}$ for $48 \mathrm{hrs}$ for the fungi, after which each test tube was observed for turbidity (growth). The MIC was the test tube with the lowest concentration of the compounds which showed no turbidity.

2.6. Minimum Bactericidal/Fungicidal Concentration. MBC (Table 3) was carried out to check whether test microorganisms were killed or only their growths were inhibited. Mueller Hinton, (Oxoid, England) and Sabouraud dextrose agar, (Oxoid, England) were prepared, sterilized, and poured into sterile Petri dishes. These were allowed to cool and solidify. The content of the MIC in the serial dilution was then subcultured onto the prepared media. These were then incubated at $37^{\circ} \mathrm{C}$ for $24 \mathrm{hrs}$ for the bacteria and $30^{\circ} \mathrm{C}$ for $48 \mathrm{hrs}$ for the fungi after which each plate was observed for colony growth. The MBC/MFC was the plate with lowest concentration of the compounds without colony growth.

\section{Results and Discussion}

A total of seven compounds were synthesized and fully characterized using 1D and 2D NMR experiments, infrared 
TABLe 1: Synthesized C-9154 analogue and its derivatives.

\begin{tabular}{|c|c|c|c|c|}
\hline Sample code & Type & Yield (mg) & Melting point $\left({ }^{\circ} \mathrm{C}\right)$ & Physical State \\
\hline $\mathrm{IA} / 12 / 1$ & C-9154 analogue & $91.7 \%$ & $125-127$ & Shiny white crystalline solid \\
\hline $\mathrm{IA} / 27 / 1 / \mathrm{B}$ & Methyl ester & $\begin{array}{c}140 \\
(0.64 \mathrm{mmol})\end{array}$ & not determined & Colourless oil \\
\hline $\mathrm{IA} / 28 / 1 / \mathrm{B}$ & Ethyl ester & $\begin{array}{c}105 \\
(0.45 \mathrm{mmol})\end{array}$ & 79 & Light yellow crystalline solid \\
\hline $\mathrm{IA} / 29 / 1 / \mathrm{B}^{*}$ & n-propyl ester & $\begin{array}{c}170 \\
(0.69 \mathrm{mmol})\end{array}$ & 40 & White crystalline solid \\
\hline $\mathrm{IA} / 30 / 1 / \mathrm{B}^{*}$ & Isopropyl ester & $\begin{array}{c}185 \\
(0.75 \mathrm{mmol})\end{array}$ & 67 & White crystalline solid \\
\hline $\mathrm{IA} / 31 / 1 / \mathrm{B}^{*}$ & n-butyl ester & $\begin{array}{c}100 \\
(0.38 \mathrm{mmol})\end{array}$ & not determined & Colourless oil \\
\hline $\mathrm{IA} / 32 / 1 / \mathrm{B}^{*}$ & 2-butyl ester & $\begin{array}{c}125 \\
(0.48 \mathrm{mmol}) \\
\end{array}$ & not determined & Colourless oil \\
\hline
\end{tabular}

* Synthesized for the first time. Confirmed from available data and on Scifinder.

TABLE 2: Zones of inhibition ( $\mathrm{mm}$ ) of the analogue and derivatives.

\begin{tabular}{|c|c|c|c|c|c|c|c|c|c|c|}
\hline & $\begin{array}{c}\text { IA/12/1 } \\
(10 \mu \mathrm{g} / \mathrm{mL})\end{array}$ & $\begin{array}{l}\text { IA } / 27 / 1 / \mathrm{B} \\
(5 \mu \mathrm{g} / \mathrm{mL})\end{array}$ & $\begin{array}{l}\mathrm{IA} / 28 / 1 / \mathrm{B} \\
(5 \mu \mathrm{g} / \mathrm{mL})\end{array}$ & $\begin{array}{l}\text { IA/29/1/B } \\
(5 \mu \mathrm{g} / \mathrm{mL})\end{array}$ & $\begin{array}{l}\mathrm{IA} / 30 / 1 / \mathrm{B} \\
(5 \mu \mathrm{g} / \mathrm{mL})\end{array}$ & $\begin{array}{l}\mathrm{IA} / 31 / 1 / \mathrm{B} \\
(5 \mu \mathrm{g} / \mathrm{mL})\end{array}$ & $\begin{array}{l}\text { IA/32/1/B } \\
(5 \mu \mathrm{g} / \mathrm{mL})\end{array}$ & DMSO & $\begin{array}{c}\text { Sparfloxacin } \\
(20 \mu \mathrm{g} / \mathrm{mL})\end{array}$ & $\begin{array}{l}\text { fluconazole } \\
(50 \mu \mathrm{g} / \mathrm{mL}) \\
\end{array}$ \\
\hline MRSA & 27 & 32 & 33 & 30 & 30 & 31 & 31 & 0 & 22 & 0 \\
\hline S. aureus & 26 & 30 & 29 & 32 & 32 & 30 & 31 & 0 & 27 & 0 \\
\hline S. pyogenes & 21 & 31 & 32 & 0 & 27 & 30 & 30 & 0 & 24 & 0 \\
\hline B. subtilis & 33 & 37 & 38 & 34 & 34 & 31 & 29 & 0 & 30 & 0 \\
\hline C. ulcerans & 24 & 0 & 30 & 32 & 30 & 0 & 0 & 0 & 0 & 0 \\
\hline E. coli & 27 & 27 & 29 & 26 & 24 & 26 & 24 & 0 & 27 & 0 \\
\hline P. mirabilis & 27 & 24 & 27 & 25 & 27 & 24 & 25 & 0 & 22 & 0 \\
\hline P. aeruginosa & 0 & 0 & 0 & 0 & 0 & 0 & 0 & 0 & 20 & 0 \\
\hline S. typhii & 29 & 27 & 26 & 27 & 24 & 27 & 27 & 0 & 21 & 0 \\
\hline S. dysenteriae & 31 & 29 & 26 & 22 & 27 & 24 & 25 & 0 & 27 & 0 \\
\hline K. pneumoniae & 30 & 27 & 25 & 26 & 24 & 26 & 25 & 0 & 25 & 0 \\
\hline C. albicans & 26 & 22 & 23 & 20 & 20 & 22 & 21 & 0 & 0 & 24 \\
\hline A. nigre & 21 & 0 & 0 & 0 & 0 & 0 & 0 & 0 & 0 & 0 \\
\hline T. rubrum & 0 & 0 & 0 & 0 & 0 & 0 & 0 & 0 & 0 & 20 \\
\hline
\end{tabular}

spectrophotometry, and gas chromatography-mass spectrometry.

The analogue was synthesized by reaction between benzylamine and maleic anhydride to get the desired fumaramic acid. This analogue was then converted to its methyl, ethyl, n-propyl, isopropyl, n-butyl, and 2-butyl esters using a modified method of the Fischer-Speier esterification.

The results are presented below.

IA/12/1 (N-benzylamino fumaramic acid). Shiny white needle-like solid; melting point, $125-127^{\circ} \mathrm{C}$.

${ }^{13} \mathrm{C}-\mathrm{NMR}$ (400 MHz, DMSO-d 6 ). 165.7 (C11), 165.2 (C8), 137.9 (C1), 132.4 (C10), 131.5 (C9), 128.4 (C2 and C6), 127.6 (C3 and C5), 127.2 (C4), 42.6 (C7).

${ }^{1} \mathrm{H}-\mathrm{NMR}\left(400 \mathrm{MHz}, \mathrm{DMSO}-\mathrm{d}_{6}\right) \delta 4.40(2.1 \mathrm{H}, \mathrm{d}, \mathrm{J}=$ $5.88 \mathrm{~Hz}, \mathrm{H}-7), 6.27(1 \mathrm{H}, \mathrm{d}, \mathrm{J}=12.41 \mathrm{~Hz}, \mathrm{H}-10), 6.45(1 \mathrm{H}, \mathrm{d}$, $\mathrm{J}=12.41 \mathrm{~Hz}, \mathrm{H}-9), 7.26-7.37(5 \mathrm{H}, \mathrm{H}-2, \mathrm{H}-3, \mathrm{H}-4, \mathrm{H}-5$ and H-6), 9.42 (1H, s, 11-OH), 14.57 (1H, s, 7-NH). EI-MS: $m / z$
$187\left\{[\mathrm{~m}-\mathrm{H}]^{+}, 100 \%\right\} . \mathrm{IR}_{v \max }$ (neat) $\mathrm{cm}^{-1}: 3247.81(\mathrm{~N}-\mathrm{H})$, $3064.54(\mathrm{O}-\mathrm{H}), 2947.47(\mathrm{C}-\mathrm{H}), 1696.92,1629.53(\mathrm{C}=\mathrm{O})$.

IA/27/1/B (Methyl N-benzylamino fumaramate). Colourless oil.

${ }^{13} \mathrm{C}-\mathrm{NMR}\left(400 \mathrm{MHz}, \mathrm{CDCl}_{3}\right) .166 .6$ (C8), 164.4 (C11), 137.9 (C1), 135.9 (C9), 126.0 (C10), 128.5 (C2 and C6), 127.8 (C3 and C5), 127.3 (C4), 52.2 (C12), 43.4 (C7).

${ }^{1} \mathrm{H}-\mathrm{NMR}\left(400 \mathrm{MHz}, \mathrm{CDCl}_{3}\right) \delta 3.65(3 \mathrm{H}, \mathrm{s}, \mathrm{H}-12), 4.40$ $(2 \mathrm{H}, \mathrm{d}, \mathrm{J}=5.80 \mathrm{~Hz}, \mathrm{H}-7), 6.02(1 \mathrm{H}, \mathrm{d}, \mathrm{J}=12.53 \mathrm{~Hz}, \mathrm{H}-$ 10), 6.23 (1H, d, J = 12.53 Hz, H-9), 7.19-7.29 (5H, H-2, H3, H-4, H-5 and H-6), 8.31 (1H, s, 7-NH). EI-MS: $m / z 219$ $\left\{[\mathrm{M}]^{+}, 25 \%\right\} . \mathrm{IR}_{v \max }$ (neat) $\mathrm{cm}^{-1}: 3284.69(\mathrm{~N}-\mathrm{H}), 2950.59$ $(\mathrm{C}-\mathrm{H}), \sim 1700.00,1634.63(\mathrm{C}=\mathrm{O})$.

IA/28/1/B (Ethyl N-benzylamino fumaramate). Light yellow crystalline solid; melting point, $79^{\circ} \mathrm{C}$. 
Table 3: Minimum Inhibitory Concentration (above) and Minimum Bactericidal/Fungicidal Concentration (below) of the analogue and derivatives $(\mu \mathrm{g} / \mathrm{mL})$.

\begin{tabular}{|c|c|c|c|c|c|c|c|c|c|c|}
\hline & IA/12/1 & IA/27/1/B & IA/28/1/B & IA/29/1/B & $\mathrm{IA} / 30 / 1 / \mathrm{B}$ & $\mathrm{IA} / 31 / 1 / \mathrm{B}$ & $\mathrm{IA} / 32 / 1 / \mathrm{B}$ & DMSO & Sparfloxacin & Fluconazole \\
\hline \multirow{2}{*}{ MRSA } & 2.5 & 0.625 & 0.625 & 0.625 & 0.625 & 0.625 & 0.625 & \multirow{2}{*}{ ND } & \multirow{2}{*}{10} & \multirow{2}{*}{ ND } \\
\hline & 5 & 2.5 & 2.5 & 5 & 2.5 & 2.5 & 5 & & & \\
\hline \multirow{2}{*}{ S. aureus } & 2.5 & 0.625 & 1.25 & 0.625 & 0.625 & 0.625 & 0.625 & \multirow{2}{*}{ ND } & \multirow{2}{*}{10} & \multirow{2}{*}{ ND } \\
\hline & 5 & 5 & 5 & 2.5 & 2.5 & 5 & 2.5 & & & \\
\hline \multirow{2}{*}{ S. pyogenes } & 2.5 & 0.625 & 0.625 & ND & 1.25 & 0.625 & 0.625 & \multirow{2}{*}{ ND } & \multirow{2}{*}{10} & \multirow{2}{*}{ ND } \\
\hline & 10 & 2.5 & 2.5 & ND & 5 & 5 & 2.5 & & & \\
\hline \multirow{2}{*}{ B. subtilis } & 1.25 & 0.625 & 0.625 & 0.625 & 0.625 & 0.625 & 1.25 & \multirow{2}{*}{ ND } & \multirow{2}{*}{5} & \multirow{2}{*}{ ND } \\
\hline & 5 & 1.25 & 1.25 & 2.5 & 2.5 & 2.5 & 5 & & & \\
\hline \multirow{2}{*}{ C. ulcerans } & 2.5 & ND & 0.625 & 0.625 & 0.625 & ND & ND & \multirow{2}{*}{ ND } & \multirow{2}{*}{ ND } & \multirow{2}{*}{ ND } \\
\hline & 10 & ND & 5 & 2.5 & 5 & ND & ND & & & \\
\hline \multirow{2}{*}{ E. coli } & 2.5 & 1.25 & 1.25 & 1.25 & 1.25 & 1.25 & 1.25 & \multirow{2}{*}{ ND } & \multirow{2}{*}{10} & \multirow{2}{*}{ ND } \\
\hline & 5 & 5 & 5 & 5 & 5 & 5 & 5 & & & \\
\hline \multirow{2}{*}{ P. mirabilis } & 2.5 & 1.25 & 1.25 & 1.25 & 1.25 & 1.25 & 1.25 & \multirow{2}{*}{ ND } & \multirow{2}{*}{10} & \multirow{2}{*}{ ND } \\
\hline & 5 & 5 & 5 & 5 & 5 & 5 & 5 & & & \\
\hline \multirow{2}{*}{ P. aeruginosa } & ND & ND & ND & ND & ND & ND & ND & & 10 & \\
\hline & ND & ND & ND & ND & ND & ND & ND & ND & 10 & ND \\
\hline S tuphii & 2.5 & 1.25 & 1.25 & 1.25 & 1.25 & 1.25 & 1.25 & ND & 10 & $\mathrm{ND}$ \\
\hline 3. гурип & 5 & 5 & 5 & 5 & 5 & 5 & 5 & & 10 & ND \\
\hline$S$ dysenteriae & 1.25 & 1.25 & 1.25 & 1.25 & 1.25 & 1.25 & 1.25 & ND & 5 & ND \\
\hline ง. aysenteriae & 5 & 5 & 5 & 5 & 5 & 5 & 5 & ND & 3 & ND \\
\hline K pneumoniae & 1.25 & 1.25 & 1.25 & 1.25 & 1.25 & 1.25 & 1.25 & ND & 5 & ND \\
\hline & 5 & 5 & 5 & 5 & 5 & 5 & 5 & ND & & \\
\hline C. albicans & 2.5 & 1.25 & 1.25 & 1.25 & 1.25 & 1.25 & 1.25 & & & \\
\hline C. alotcants & 5 & 5 & 5 & 5 & 5 & 5 & 5 & ND & ND & 25 \\
\hline A. nigre & 2.5 & ND & ND & ND & ND & ND & ND & ND & ND & ND \\
\hline A. nigre & 10 & ND & ND & ND & ND & ND & ND & ND & ND & ND \\
\hline T. rubrum & ND & ND & ND & ND & ND & ND & ND & ND & ND & 25 \\
\hline & ND & ND & ND & ND & ND & ND & ND & ND & ND & $2 J$ \\
\hline
\end{tabular}

Upper values are MIC and lower values are MBC or MFC as the case may be. ND: Not Determined.

${ }^{13} \mathrm{C}-\mathrm{NMR}\left(400 \mathrm{MHz}, \mathrm{CDCl}_{3}\right) .165 .7$ (C8), 163.6 (C11), 137.5 (C1), 136.3 (C9), 130.6 (C10), 128.8 (C2 and C6), 127.9 (C3 and C5), 127.8 (C4), 61.2 (C7), 44.0 (C12), 14.1(C13).

${ }^{1} \mathrm{H}-\mathrm{NMR}\left(400 \mathrm{MHz}, \mathrm{CDCl}_{3}\right) \delta 1.21(3 \mathrm{H}, \mathrm{t}, \mathrm{J}=7.12 \mathrm{~Hz}$, $\mathrm{H}-13), 4.13(2 \mathrm{H}, \mathrm{q}, \mathrm{J}=7.15 \mathrm{~Hz}, \mathrm{H}-12), 4.42(2 \mathrm{H}, \mathrm{d}$, $\mathrm{J}=5.72 \mathrm{~Hz}, \mathrm{H}-7), 6.02(1 \mathrm{H}, \mathrm{d}, \mathrm{J}=12.77 \mathrm{~Hz}, \mathrm{H}-10)$, $6.23(1 \mathrm{H}, \mathrm{d}, \mathrm{J}=12.93 \mathrm{~Hz}, \mathrm{H}-9), 7.18-7.27(5 \mathrm{H}, \mathrm{H}-2, \mathrm{H}-$ $3, \mathrm{H}-4, \mathrm{H}-5$ and $\mathrm{H}-6), 8.46(1 \mathrm{H}, \mathrm{s}, 7-\mathrm{NH})$. EI-MS: $\mathrm{m} / \mathrm{z}$ $106\left\{[\mathrm{~m}+\mathrm{H}]^{+}, 100 \%\right\} . \mathrm{IR}_{v \max }$ (neat) $\mathrm{cm}^{-1}: 3320.01(\mathrm{~N}-$ $\mathrm{H}), 2989.28(\mathrm{C}-\mathrm{H}), 1706.65,1664.23(\mathrm{C}=\mathrm{O})$.

IA/29/1/B (n-propyl N-benzylamino fumaramate). White crystalline solid; melting point, $40^{\circ} \mathrm{C}$.

${ }^{13} \mathrm{C}-\mathrm{NMR}\left(400 \mathrm{MHz}, \mathrm{CDCl}_{3}\right) .166 .3$ (C8), 164.0 (C11), 137.9 (C1), 138.1 (C9), 125.6 (C10), 128.6 (C2 and C6), 127.8 (C3 and C5), 127.4 (C4), 67.2 (C7), 43.7 (C12), 21.8 (C-13), 10.3 (C14).

${ }^{1} \mathrm{H}-\mathrm{NMR}\left(400 \mathrm{MHz}, \mathrm{CDCl}_{3}\right) \delta 0.87(3 \mathrm{H}, \mathrm{t}, \mathrm{J}=7.44 \mathrm{~Hz}$, $\mathrm{H}-14), 1.60$ (2H, m, H-13), $4.03(2 \mathrm{H}, \mathrm{t}, \mathrm{J}=6.72 \mathrm{~Hz}, \mathrm{H}-12)$, $4.43(2 \mathrm{H}, \mathrm{d}, \mathrm{J}=5.68 \mathrm{~Hz}, \mathrm{H}-7), 6.05(1 \mathrm{H}, \mathrm{d}, \mathrm{J}=13.05 \mathrm{~Hz}$, $\mathrm{H}-10), 6.25(1 \mathrm{H}, \mathrm{d}, \mathrm{J}=13.01 \mathrm{~Hz}, \mathrm{H}-9), 7.16-7.27(5 \mathrm{H}, \mathrm{H}-2$, $\mathrm{H}-3, \mathrm{H}-4, \mathrm{H}-5$ and $\mathrm{H}-6), 8.54(1 \mathrm{H}, \mathrm{s}, 7-\mathrm{NH})$. EI-MS: $m / z$ $106\left\{[\mathrm{~m}+\mathrm{H}]^{+}, 100 \%\right\} . \mathrm{IR}_{v \max }$ (neat) $\mathrm{cm}^{-1}: 3275.38(\mathrm{~N}-$ H), $2967.66(\mathrm{C}-\mathrm{H}), 1721.33,1651.91(\mathrm{C}=\mathrm{O})$.
IA/30/1/B (Isopropyl N-benzylamino fumaramate). White crystalline solid; melting point, $67^{\circ} \mathrm{C}$.

${ }^{13} \mathrm{C}-\mathrm{NMR}\left(400 \mathrm{MHz}, \mathrm{CDCl}_{3}\right) .165 .8$ (C8), 164.0 (C11), 137.9 (C1), 138.3 (C9), 126.0 (C10), 128.6 (C2 and C6), 127.8 (C3 and C5), 127.4 (C4), 69.5 (C12), 43.7 (C7), 21.7 (C13 and C14).

${ }^{1} \mathrm{H}-\mathrm{NMR}\left(400 \mathrm{MHz}, \mathrm{CDCl}_{3}\right) \delta 1.27(6 \mathrm{H}, \mathrm{d}, \mathrm{J}=6.52 \mathrm{~Hz}$, $\mathrm{H}-13$ and $\mathrm{H}-14), 4.54(2 \mathrm{H}, \mathrm{d}, \mathrm{J}=5.72 \mathrm{~Hz}, \mathrm{H}-7), 5.06(1 \mathrm{H}$, m, H-12), $6.11(1 \mathrm{H}, \mathrm{d}, \mathrm{J}=13.13 \mathrm{~Hz}, \mathrm{H}-10), 6.34(1 \mathrm{H}, \mathrm{d}, \mathrm{J}=$ 13.13 Hz, H-9), 7.25-7.36 (5H, H-2, H-3, H-4, H-5 and $\mathrm{H}-$ 6), $8.75(1 \mathrm{H}, \mathrm{s}, 7-\mathrm{NH})$. EI-MS: $m / z 106\left\{[\mathrm{~m}+\mathrm{H}]^{+}, 100 \%\right\}$. $\mathrm{IR}_{v \max }$ (neat) $\mathrm{cm}^{-1}: 3230.92(\mathrm{~N}-\mathrm{H}), 2931.87(\mathrm{C}-\mathrm{H}), \quad$ $1700.00,1650.74(\mathrm{C}=\mathrm{O})$.

IA/31/1/B (n-butyl N-benzylamino fumaramate). Colourless oil.

${ }^{13} \mathrm{C}-\mathrm{NMR}\left(400 \mathrm{MHz}, \mathrm{CDCl}_{3}\right) .166 .3$ (C8), 164.3 (C11), 138.0 (C1), 136.2 (C9), 126.2 (C10), 128.5 (C2 and C6), 127.7 (C3 and C5), 127.3 (C4), 65.2 (C12), 43.4 (C7), 30.4 (C13), 19.0 (C14), 13.6 (C15).

${ }^{1} \mathrm{H}-\mathrm{NMR}\left(400 \mathrm{MHz}, \mathrm{CDCl}_{3}\right) \delta 0.80(3 \mathrm{H}, \mathrm{t}, \mathrm{J}=7.38 \mathrm{~Hz}$, H-15), 1.24 (2H, m, H-14), 1.49 (2H, m, H-13), $3.99(2 \mathrm{H}$, $\mathrm{t}, \mathrm{J}=6.72 \mathrm{~Hz}, \mathrm{H}-12), 4.31(2 \mathrm{H}, \mathrm{d}, \mathrm{J}=5.84 \mathrm{~Hz}, \mathrm{H}-7), 5.92$ $(1 \mathrm{H}, \mathrm{d}, \mathrm{J}=12.61 \mathrm{~Hz}, \mathrm{H}-10), 6.13(1 \mathrm{H}, \mathrm{d}, \mathrm{J}=12.65 \mathrm{~Hz}, \mathrm{H}-9)$, 7.08-7.19 (5H, H-2, H-3, H-4, H-5 and H-6), $8.36(1 \mathrm{H}, \mathrm{s}$, 
7-NH). EI-MS: $m / z 106\left\{[\mathrm{~m}+\mathrm{H}]^{+}, 100 \%\right\}$. $\operatorname{IR}_{v \max }$ (neat) $\mathrm{cm}^{-1}: 3290.40(\mathrm{~N}-\mathrm{H}), 2958.75(\mathrm{C}-\mathrm{H}), 1722.82,1632.07$ $(\mathrm{C}=\mathrm{O})$.

IA/32/1/B (2-butyl N-benzylamino fumaramate). Colourless oil.

${ }^{13} \mathrm{C}-\mathrm{NMR}\left(400 \mathrm{MHz}, \mathrm{CDCl}_{3}\right) .165 .9$ (C8), 164.3 (C11), 138.0 (C1), 136.4 (C9), 126.5 (C10), 128.5 (C2 and C6), 127.7 (C3 and C5), 127.2 (C4), 73.7 (C12), 43.5 (C7), 28.6 (C13), 19.1 (C15), 9.6 (C14).

${ }^{1} \mathrm{H}-\mathrm{NMR}\left(400 \mathrm{MHz}, \mathrm{CDCl}_{3}\right) \delta 0.87(3 \mathrm{H}, \mathrm{t}, \mathrm{J}=7.50 \mathrm{~Hz}$, $\mathrm{H}-14), 1.21(3 \mathrm{H}, \mathrm{d}, \mathrm{J}=6.24 \mathrm{~Hz}, \mathrm{H}-15), 1.56$ (2H, m, H-13), $4.43(2 \mathrm{H}, \mathrm{d}, \mathrm{J}=5.80 \mathrm{~Hz}, \mathrm{H}-7), 4.87(1 \mathrm{H}, \mathrm{m}, \mathrm{H}-12), 6.03$ $(1 \mathrm{H}, \mathrm{d}, \mathrm{J}=12.69 \mathrm{~Hz}, \mathrm{H}-9), 6.23(1 \mathrm{H}, \mathrm{d}, \mathrm{J}=12.77 \mathrm{~Hz}, \mathrm{H}-10)$, 7.19-7.30 (5H, H-2, H-3, H-4, H-5 and H-6), 8.57 (1H, s, 7-NH). EI-MS: $m / z 106\left\{[\mathrm{~m}+\mathrm{H}]^{+}, 100 \%\right\}$. $\operatorname{IR}_{v \max }$ (neat) $\mathrm{cm}^{-1}: 32.91 .43(\mathrm{~N}-\mathrm{H}), 2972.45(\mathrm{C}-\mathrm{H}), 1719.24,1636.62$ $(\mathrm{C}=\mathrm{O})$.

The results show that the synthesized antibiotics had remarkable activity in the range $0.625-10 \mu \mathrm{g} / \mathrm{mL}$ against the microorganisms for which they were active against.

The derivatives showed higher activity than the analogue as expected. This could be due to the reduction in polarity when the highly polar carboxylic functional group was converted to the less polar ester functional group. This has been shown to increase cell membrane permeability [11-13].

All the synthesized compounds showed better activity than the standard drugs used for comparison. The antibacterial standard drug, sparfloxacin, was up to fourfold less active than most of the synthesized derivatives while the antifungal standard drug, fluconazole, was up to tenfold less active than the synthesized analogue and derivatives for the microorganism against which they were active. All the synthesized compounds except, IA/27/1/B, IA/31/1/B, and $\mathrm{IA} / 32 / 1 / \mathrm{B}$ were able to inhibit the growth of $C$. ulcerans whereas the standard antibacterial could not. All the derivatives and the standard antifungal could not inhibit the growth of $A$. nigre, but the analogue (IA/12/1) was able to inhibit its growth. All the synthesized compounds could not inhibit the growths of $P$. aeruginosa and T. rubrum and one of the synthesized compounds (IA/29/1/B) could also not inhibit the growth of $S$. pyogenes.

\section{Conclusion}

The results show that the synthesized compounds have a clear advantage over the tested standard drugs, and this has opened up the possibility of their application in the treatment of various ailments for which the tested microorganisms are responsible for.

The possible applications of these compounds are endless and with further studies could compliment or even replace some of the antibiotic drugs currently in the market if they are found to be less toxic and better tolerated. Other applications for the new antibiotics are in the veterinary and agricultural fields where they could be useful in combatting some of the diseases that plague both animals and plants.
Some in vivo work is being carried out to establish the activity of the synthesized compounds as anticancer, anti-HIV, antimalarial, antitrypanosomiasis, antituberculosis, and so forth.

\section{Acknowledgment}

I. A. Bello would like to appreciate the ETF, Nigeria for sponsoring part of this project. The authors declare that they do not have any direct or indirect financial relation with any commercial entity mentioned in this paper and also no conflict of interests whatsoever.

\section{References}

[1] S. M. Aronson, "The naming of antibiotics," Medicine and Health, vol. 80, no. 6, p. 180, 1997.

[2] M. Radetsky, "The discovery of penicillin," The Pediatric Infectious Disease Journal, vol. 15, no. 9, pp. 811-818, 1996.

[3] S. A. Waksman, "What Is an antibiotic or an antibiotic substance?” Mycologia, vol. 39, no. 5, pp. 565-569, 1947.

[4] F. Von Nussbaum, M. Brands, B. Hinzen, S. Weigand, and D. Häbich, "Antibacterial natural products in medicinal chemistry-exodus or revival?" Angewandte Chemie, vol. 45, no. 31, pp. 5072-5129, 2006.

[5] H. B. Maruyama, Y. Suhara, J. Suzuki Watanabe et al., "A new antibiotic, fumaramidmycin. I. Production, biological properties and characterization of producer strain," Journal of Antibiotics, vol. 28, no. 9, pp. 636-647, 1975.

[6] T. Hasegawa, M. Asai, and K. Haibara, "A new antibiotic, C9154,” Journal of Antibiotics, vol. 28, no. 9, pp. 713-716, 1975.

[7] Y. Suhara, H. B. Maruyama, and Y. Kotoh, "A new antibiotic, fumaramidmycin. II. Isolation, structure and syntheses," Journal of Antibiotics, vol. 28, no. 9, pp. 648-655, 1975.

[8] J. Jumina, D. Siswanta, and A. K. Zulkarnain, "Sintesis dan Uji Aktivitas Biologis Turunan Antibiotik C-9154 Dari Vanilin," Majalah Farmasi Indonesia, vol. 12, no. 3, pp. 24-35, 2001.

[9] J. Jumina, I. Tahir, and A. K. Zulkarnain, "Synthesis and antimicrobe activity evaluation of ethyl salicyl fumarate and ethyl furfuryl fumarate," Majalah Farmasi Indonesia, vol. 13, no. 4, pp. 207-214, 2002.

[10] J. Jumina, A. K. Zulkarnain, and P. Mulyono, "Preparation and antibacterial activity of p-Anisyl ethyl fumarate and ethyl $\mathrm{N}$ phenyl fumaramate," Majalah Farmasi Indonesia, vol. 16, no. 2, pp. 116-123, 2005.

[11] F. L. Strand, "The plasma membrane as a regulatory organelle," in Physiology: A Regulatory Systems Approach, pp. 49-67, MacMillan, New York, NY, USA, 2nd edition, 1983.

[12] R. Eckert, D. Randall, and G. Augustine, "Permeability and transport," in Animal Physiology, pp. 65-99, W. H. Freeman, New York, NY, USA, 3rd edition, 1988.

[13] B. Alberts, D. Bray, J. Lewis, M. Raff, K. Roberts, and J. D. Watson, "The Plasma membrane," in Molecular Biology of the Cell, pp. 276-337, Garland Publishing, New York, NY, USA, 2nd edition, 1989. 


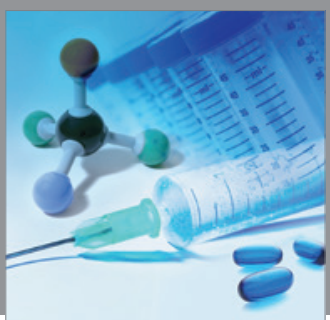

International Journal of

Medicinal Chemistry

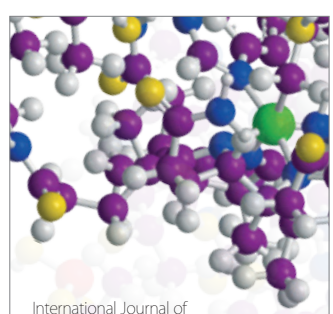

Carbohydrate Chemistry

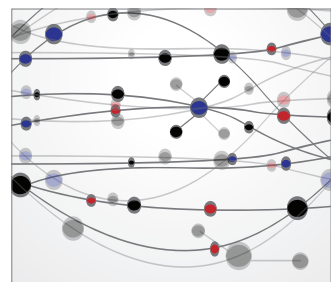

The Scientific World Journal
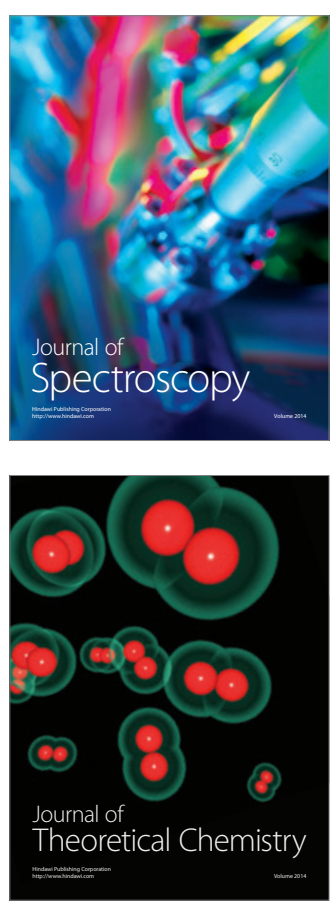
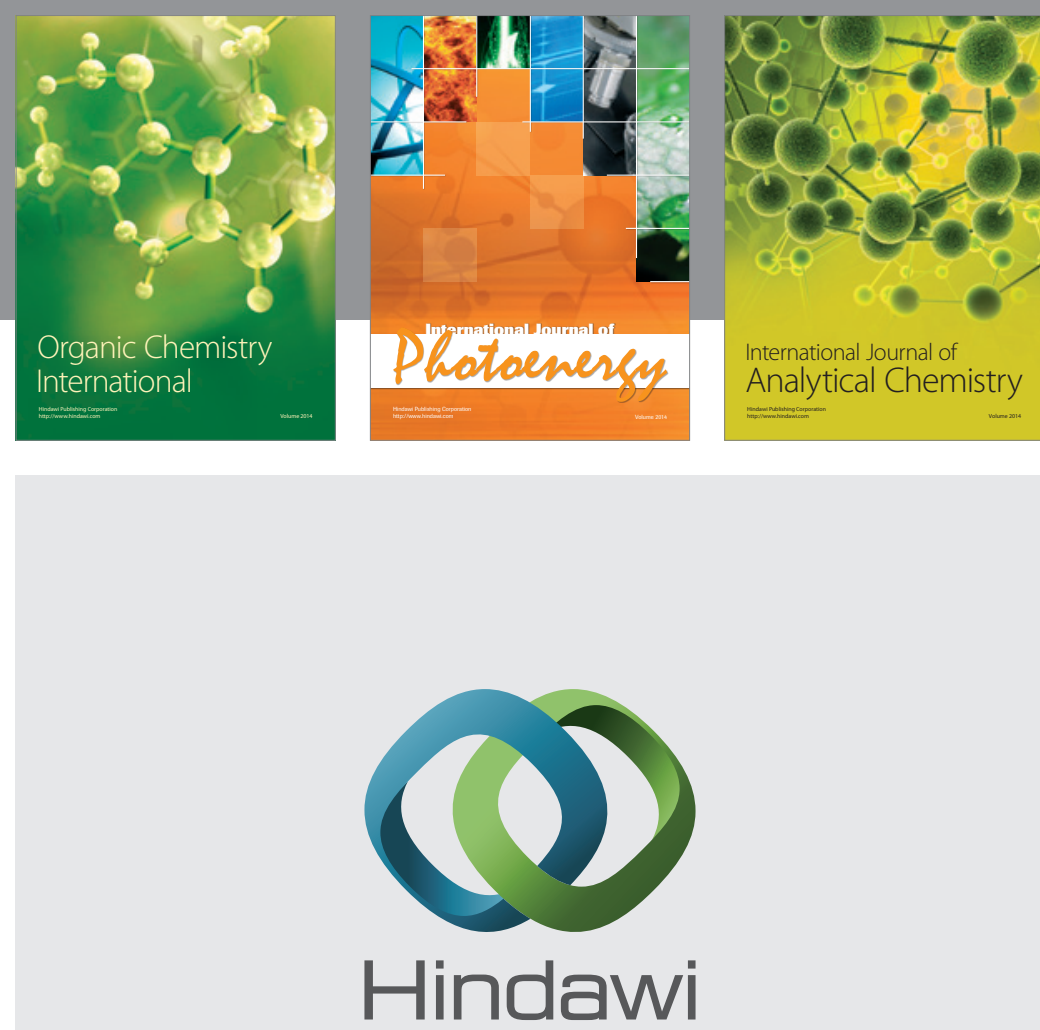

Submit your manuscripts at

http://www.hindawi.com
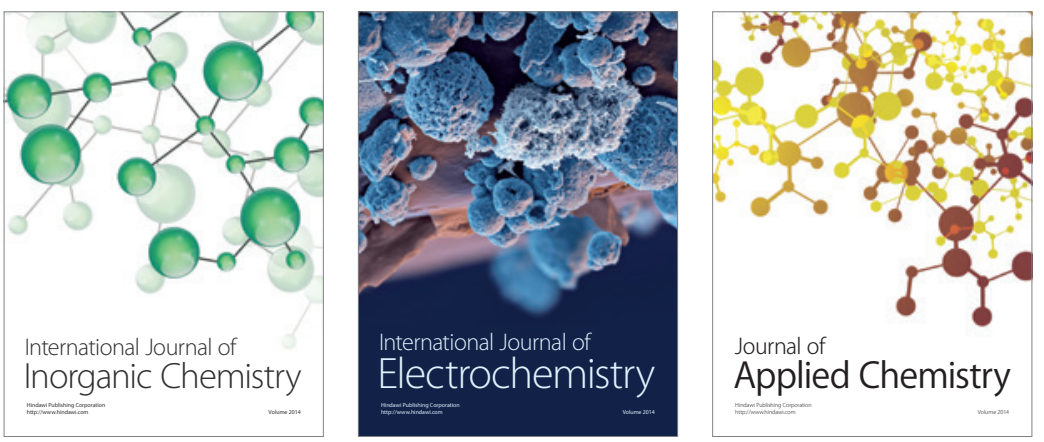

Journal of

Applied Chemistry
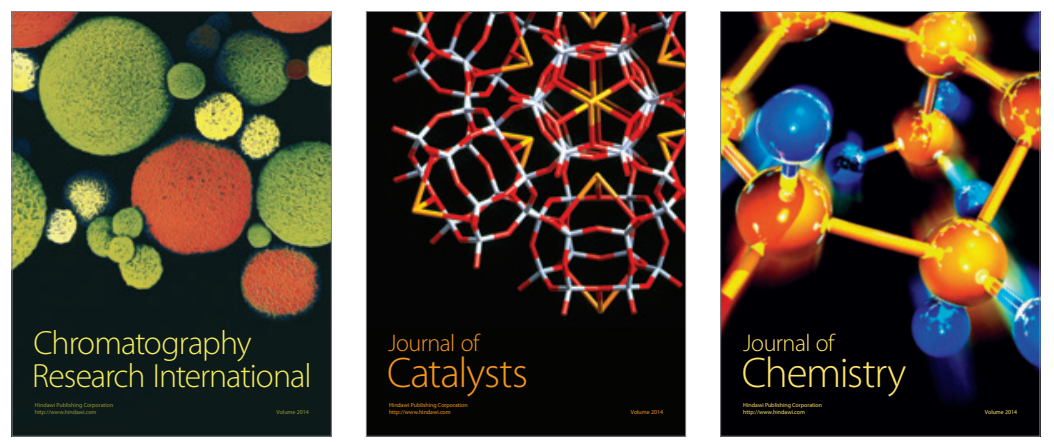
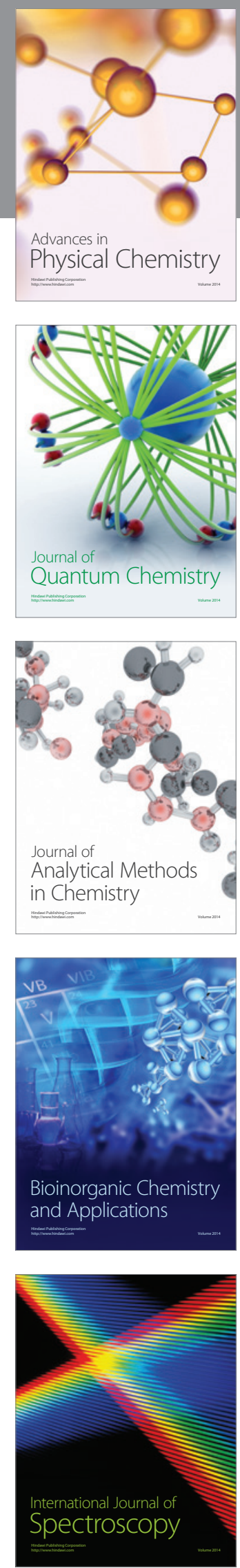